Check for updates

Cite this: RSC Adv., 2018, 8, 29548

Received 5th July 2018

Accepted 10th August 2018

DOI: 10.1039/c8ra05728a

rsc.li/rsc-advances

\section{Structural modification of oridonin via DAST induced rearrangement $\uparrow$}

\author{
Dong-Dong Luo, $\$^{\mathrm{a}}$ Kai Peng, $\$^{\mathrm{a}}$ Jia-Yu Yang, ${ }^{\mathrm{a}}$ Pawinee Piyachaturawat, ${ }^{\mathrm{b}}$ \\ Witchuda Saengsawang, ${ }^{\mathrm{b}}$ Lei Ao, ${ }^{\mathrm{C}}$ Wan-Zhou Zhao, ${ }^{\mathrm{C}}$ Yu Tang (D) *a \\ and Sheng-Biao Wan ${ }^{\star a}$
}

A simple and efficient protocol was developed for the syntheses of oridonin analogues, i.e. 6,20-epoxy entkaurane diterpenoid analogues from oridonin via diethylaminosulfur trifluoride (DAST) promoted rearrangement, most of which exhibited superior anticancer activities compared with their precursor.

\section{Introduction}

Oridonin, an ent-kaurane diterpenoid extracted from Isodon rubescens (Chinese name "Donglingcao"), has received particular interest from the pharmaceutical community ${ }^{1,2}$ due to its pharmacological utilities, e.g. unique and prominent anticancer activity $^{3}$ as well as its safety. It has been demonstrated that oridonin could significantly suppress cancer cell migration via regulation of non-muscle myosin IIA. ${ }^{4}$ The anticancer mechanism of oridonin in vitro may involve multiple pathways, ${ }^{5-13}$ for instance, oridonin can not only inhibit the proliferation of the breast cancer cell McF-7, but also induce apoptosis through the pathways of hampering the cell cycle and activation of mitochondria. ${ }^{914-18}$ Targeting AML1-ETO (AE) fusion protein which plays a critical role in leukemogenesis shows potent antitumor activity with low adverse effects on $\mathrm{t}(8 ; 21)$ leukemia in vitro and in vivo. ${ }^{19}$ However, the clinical application of oridonin has been significantly impeded by its poor aqueous solubility, moderate potency, low bioavailability ${ }^{20}$ and metabolic instability. ${ }^{21}$ Thus it's highly desirable to synthesize the oridonin analogues via rational chemical modification of its structure for better pharmacological properties such as anticancer activity.

Oridonin belongs to the class of 7,20-epoxy ent-kaurane diterpenoid structures, which features 1,6,14-trihydroxy groups, 7-hemiacetal moiety in the B-ring and the $\alpha$-methylene

${ }^{a}$ Laboratory for Marine Drugs and Bioproducts of Qingdao National Laboratory for Marine Science and Technology, Key Laboratory of Marine Drugs, Ministry of Education, School of Medicine and Pharmacy, Ocean University of China, Yushan Road 5, Qingdao 266003, China. E-mail: biaowan@ouc.edu.cn; tangyu@ouc.edu.cn; Tel: $+86-532-82031087$

${ }^{b}$ Department of Physiology, Faculty of Science, Mahidol University, Bangkok 10400, Thailand

'The Nanjing Han \& Zaenker Cancer Institute (NHZCI), Nanjing OGpharma Co. Ltd., Nanjing 210036, China

$\dagger$ Electronic supplementary information (ESI) available: CCDC 1590323. For ESI and crystallographic data in CIF or other electronic format see DOI: $10.1039 / \mathrm{c} 8 \mathrm{ra05728 \textrm {a }}$

$\ddagger$ These authors contributed equally to this work. cyclopentanone in the D-ring. The strong hydrogen bonding interaction exists between $6 \beta-\mathrm{OH}$ and carbonyl group at C-15 (Fig. 1). It's difficult for $6 \beta-\mathrm{OH}$ and $7 \beta-\mathrm{OH}$ to participate in nucleophilic reaction due to the adjacent steric hindrance and the intramolecular hydrogen bonding interaction. The previous studies of oridonin on the structure-activity relationship (SAR) have proved that D-ring is crucial to anti-cancer activity, ${ }^{22,23}$ and any modification of enone moiety ${ }^{24}$ would lead to loss of anticancer activity. ${ }^{25}$ As shown in Fig. 1, previous efforts on structural modification of oridonin were mainly focused on $\mathrm{A}$ ring, ${ }^{2,26-28} 6-O$ positions ${ }^{29}$ and $14-O$ positions ${ }^{17,30,31}$ as well as Bring opening via oxidative cleavage of $\mathrm{C}-\mathrm{C}$ bond between $\mathrm{C}-6$ and C-7. ${ }^{31}$

Diethylaminosulfur trifluoride (DAST) has been employed as a versatile fluorinating agent for various fluorination reactions, ${ }^{32-34}$ e.g. fluorination of carbohydrate in which structural

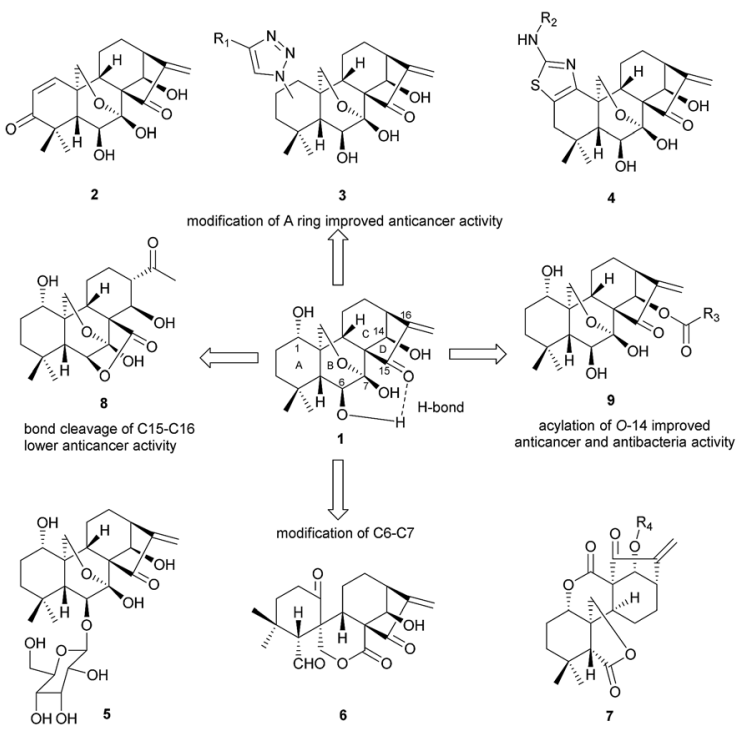

Fig. 1 Structures of oridonin and biologically active analogues. 

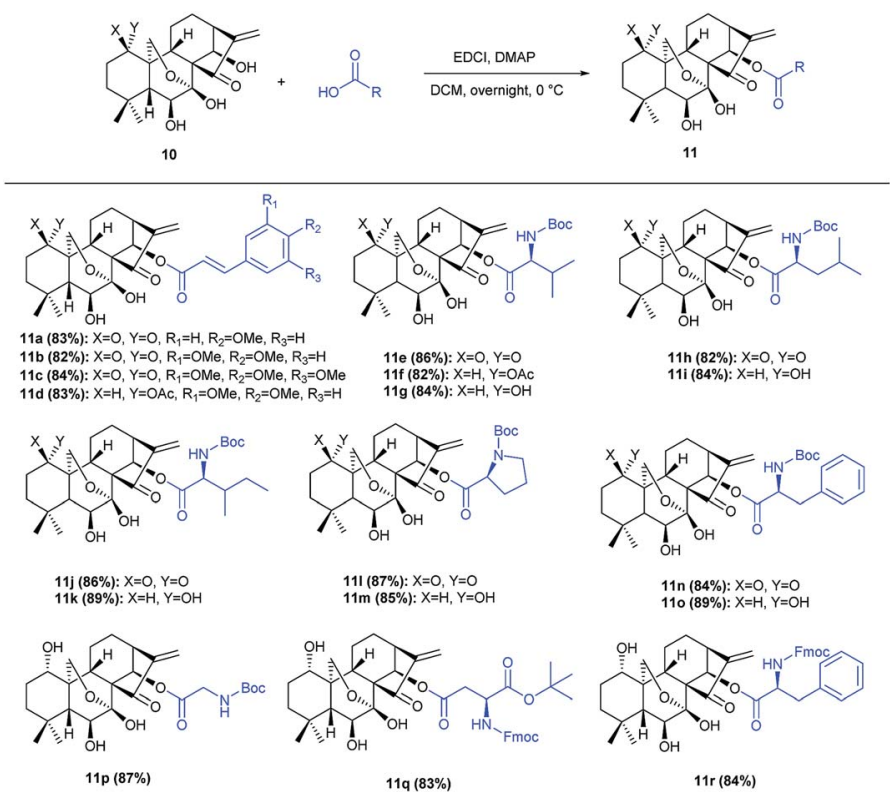

Scheme 1 Synthesis of 14-acyl oridonin analogues 11.

rearrangements could be observed..$^{34-37}$ Therefore, it can be envisioned that the similar structural rearrangements of oridonin could occur in the presence of DAST, yielding new oridonin analogues. As a continuation of our research works on pharmaceutical molecules, ${ }^{38,39}$ herein, we disclosed a simple and efficient method for preparation of novel 6,20-epoxy entkaurane diterpenoid analogues from oridonin, in which 6,20endo ring was formed via DAST promoted rearrangement.

\section{Results and discussion}

Our currently ongoing research works indicated that new potent antitumor agents could be produced via installing protected amino acid residues or cinnamyl group at C-14 position of oridonin analogues. Thus, oridonin analogues 11a-11r were prepared in good yields through esterification of oridonin, 1acetyl-oridonin and 1-oxo-oridonin derivatives with 4-methoxy cinnamylic acid, 3,4-dimethoxy cinnamic acid, 3,4,5-trimethoxy cinnamic acid, Boc-Gly, Boc-L-Val, Boc-L-Leu, Boc-L-Ile, Boc-LPro, Boc-L-Phe, N-Fmoc-L-Asp-1-OtBu, Fmoc-L-Phe (Scheme 1), which would be exploited as substrates for rearrangement.

Initially, the feasibility of rearrangement was investigated using readily accessed 1-oxo-14-acyl oridonin analogue $\mathbf{1 1 b}$ as the model substrate in the presence of DAST (1 equiv.) with dichloromethane (DCM) as solvent, and gratifyingly the desired product $\mathbf{1 2 b}$ was furnished in $31 \%$ yield, the structure of which was determined unambiguously by X-ray crystallography (CCDC 1590323) (Table 1, entry 1). Afterwards, the impact of DAST amount on the reaction was examined, and the yields of $12 \mathrm{~b}$ could be increased to $40 \%$, $57 \%$ and $80 \%$, respectively with 3 equivalents, 5 equivalents and 10 equivalents of DAST employed (Table 1, entries 2-4). However, further increasing the amount of DAST led to inferior yield (Table 1, entry 5). The reaction temperature was also evaluated, and the reaction could be significantly accelerated at higher temperature, which, however, had a detrimental influence on the yield (Table 1, entry 6). Subsequently, various solvents were screened, and DCM was identified as the optimal one which furnished 12b in highest yield (Table 1, entry 4). The employment of other solvents such as THF, MeCN, DMF and DMSO resulted in inferior yields (Table 1, entry 7-11), and notably, only a trace amount of $\mathbf{1 2 b}$ was observed using acetone as solvent (Table 1, entry 11).

Other strategies for this rearrangement were also investigated for more efficient transformation and more environmentally benign conditions. Intriguingly, a trace amount of $\mathbf{1 2 b}$ could be observed under Swern oxidation condition using DMSO, $(\mathrm{COCl})_{2}$ and $\mathrm{i}-\mathrm{Pr}_{2} \mathrm{NEt}$ (for details, see the $\mathrm{ESI} \uparrow$ control

Table 1 Optimization of the reaction conditions ${ }^{a}$

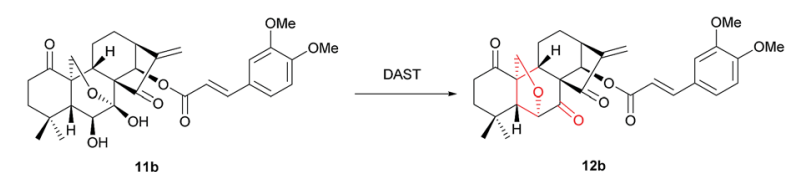

\begin{tabular}{llll}
\hline Entry & Reagent (equiv.) & Solvent & Yield $^{b}(\%)$ \\
\hline 1 & DAST (1) & DCM & 31 \\
2 & DAST (3) & DCM & 40 \\
3 & DAST (5) & DCM & 57 \\
$4^{c}$ & DAST (10) & DCM & 80 \\
$5^{c}$ & DAST (12) & DCM & 77 \\
$6^{d}$ & DAST (10) & DCM & 68 \\
$7^{e}$ & DAST (10) & THF & 61 \\
$8^{e}$ & DAST (10) & MeCN & 54 \\
$9^{e}$ & DAST (10) & DMF & 61 \\
$10^{f}$ & DAST (10) & DMSO & 36 \\
$11^{e}$ & DAST (10) & Acetone & Trace
\end{tabular}

${ }^{a}$ Reaction condition: 11b $(0.09 \mathrm{mmol})$, solvent $(5.0 \mathrm{~mL}),-78{ }^{\circ} \mathrm{C}$ for $10 \mathrm{~min}$, then warmed up to room temperature for $8 \mathrm{~h}$. ${ }^{b}$ Yield of isolated products. ${ }^{c}-78{ }^{\circ} \mathrm{C}$ for $10 \mathrm{~min}$, then warmed up to rt for $2 \mathrm{~h}$. ${ }^{d}-78{ }^{\circ} \mathrm{C}$ for $10 \mathrm{~min}$, then warmed up to $40{ }^{\circ} \mathrm{C}$ for $1 \mathrm{~h} .{ }^{e}-78{ }^{\circ} \mathrm{C}$ for $10 \mathrm{~min}$, then warmed up to rt for $3 \mathrm{~h} .{ }^{f}$ Room temperature for $3 \mathrm{~h}$. 


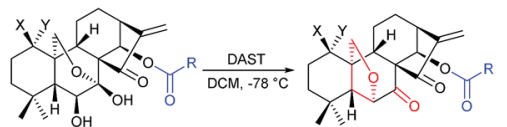

11 12

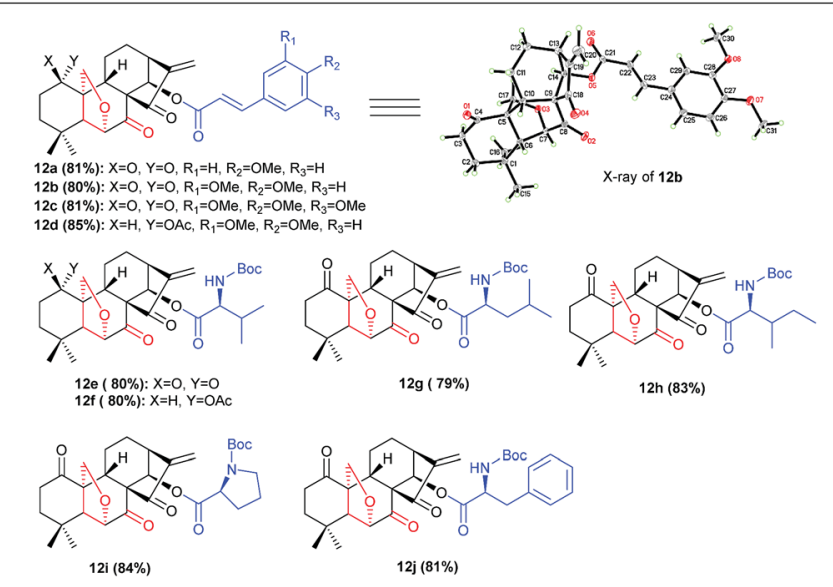

Scheme 2 Synthesis of novel 6,20-epoxy ent-kaurane diterpenoid 12.

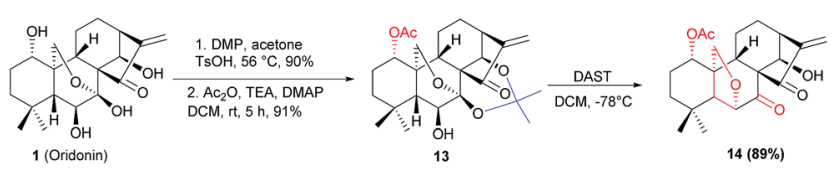

Scheme 3 Synthesis of 6,20-epoxy-14-OH ent-kaurane diterpenoid 14.

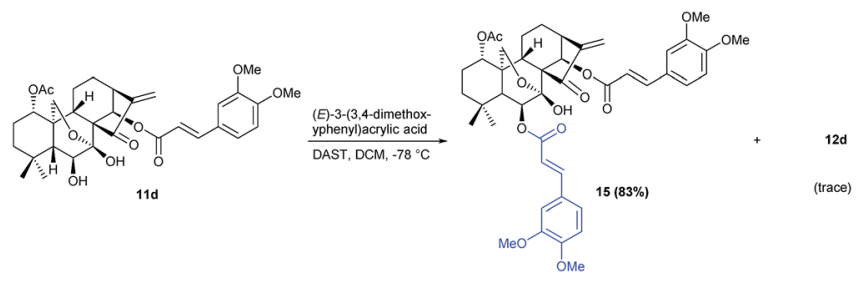

Scheme 4 Synthesis of 1-acetyl-6,14-diyl oridonin analogue 15.

experiments). Afterwards, 11b was subjected to Mitsunobu condition using 3,4,5-trimethoxybenzoic acid, $\mathrm{PPh}_{3}$ and DIAD in anhydrous THF, whereas no $\mathbf{1 2 b}$ was found. Finally, various Brønsted and Lewis acids, e.g. $p$ - $\mathrm{TsOH}, \mathrm{CF}_{3} \mathrm{SO}_{3} \mathrm{H}, \mathrm{HCl}, \mathrm{AlCl}_{3}$ (for details see the ESI Table $\mathrm{S}-1 \dagger$ ), were evaluated as catalyst for dehydroxylation, however, no $\mathbf{1 2 b}$ could be detected, which suggested that the acidic additive could thoroughly block the transformation.

Under the optimal conditions, the generality of this protocol was investigated with sterically and electronically diverse substrates subjected to this rearrangement reaction. Gratifyingly, most of the substrates 11a-11r, were well tolerated, furnishing a series of 6,20-epoxy-14-acyl ent-kaurane diterpenoids 12a-12j in 79-84\% yields (Scheme 2). Notably, the incorporated functionalities had a trivial impact on the transformation. Subsequently, aiming to prepare oridonin analogues carrying unprotected hydroxyl at C-14, the substrate 13 was synthesized via protection of 7,14-dihydroxyl of oridonin with 2,2-dimethoxypropane followed by acetylation with $\mathrm{Ac}_{2} \mathrm{O}$, and satisfyingly the correspondingly 6,20-epoxy-14-OH ent-kaurane diterpenoid 14 was delivered in 89\% yield with 13 treated with DAST (Scheme 3).

Interestingly, when 11d was treated with DAST in the presence of (E)-3-(3,4-dimethoxyphenyl)acrylic acid, the 1-acetyl6,14-diacyl oridonin analogue 15 was isolated as the main product instead in $83 \%$ yield and only trace of $\mathbf{1 2 d}$ was obtained (Scheme 4).

Based on these experimental results, a plausible mechanism was proposed (Scheme 5). Initially, 11d reacts with DAST to produce the intermediate 16, which undergoes an intramolecular nucleophilic substitution to furnish the bicyclic oxiranium ion intermediate 17. Due to the basic nature of fluorine anion and comparative strong acidity of 7-OH, the hydroxyl group is readily deprotonated, followed by the opening of oxiranium ion moiety to yield $12 d$ (route a). In contrast, an alternative reaction pathway (route b) might operate in the presence of 3,4-dimethoxycinnamic acid, the oxiranium ion moiety can be preferentially attacked by the more nucleophilic carboxylate anion of 3,4dimethoxycinnamic acid to give the product $\mathbf{1 5 .}$

The in vitro cytotoxicity of some products were determined by the methylthiazol tetrazolium (MTT) assay on the human hepatic carcinoma cell (HepG2), human multiple myeloma cell (RPMI-8226), human lung carcinoma (A549) cell lines with the commercial anticancer drug, paclitaxel (PTX), as the positive control. The results were summarized in Table 2. Notably, 11i $\left(\mathrm{IC}_{50}=0.98 \mu \mathrm{M}\right)$ and $14\left(\mathrm{IC}_{50}=2.07 \mu \mathrm{M}\right)$ exhibited potent inhibitory activities against HepG2 cell line. Compound 11e $\left(\mathrm{IC}_{50}=7.60 \mu \mathrm{M}\right)$ was found to be a potent cytotoxic agent against A549 cell lines (Fig. 2). In addition, to obtain the cytotoxicity of these new compounds on normal human cells, the

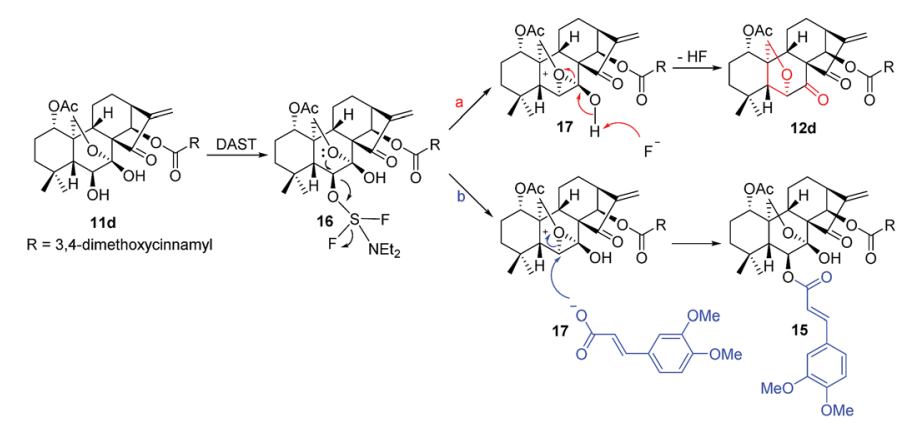

Scheme 5 A possible reaction mechanism. 
Table 2 Cytotoxicity values of some compounds towards three selected tumor cell lines for $72 \mathrm{~h}^{a}$

Cytotoxicity $\left(\mathrm{IC}_{50}, \mu \mathrm{M}\right)$

\begin{tabular}{lrcr} 
Compounds & \multicolumn{1}{c}{ HepG2 } & RPMI-8226 & \multicolumn{1}{c}{ A549 } \\
\hline Oridonin & $7.93 \pm 1.25$ & $9.84 \pm 0.41$ & $22.64 \pm 1.28$ \\
PTX & $0.19 \pm 0.03$ & $1.40 \pm 0.50$ & $0.44 \pm 0.26$ \\
$\mathbf{1 1 e}$ & $13.81 \pm 2.27$ & $19.55 \pm 2.07$ & $7.60 \pm 0.74$ \\
$\mathbf{1 1 g}$ & $10.75 \pm 1.21$ & $>100$ & $21.14 \pm 1.43$ \\
$\mathbf{1 1 h}$ & $16.07 \pm 0.53$ & $10.96 \pm 1.06$ & $19.35 \pm 1.05$ \\
$\mathbf{1 1 i}$ & $0.98 \pm 0.10$ & $11.53 \pm 1.33$ & $19.82 \pm 1.14$ \\
$\mathbf{1 1 j}$ & $15.28 \pm 1.90$ & $>100$ & $18.13 \pm 3.20$ \\
$\mathbf{1 1 k}$ & $15.28 \pm 1.90$ & $>100$ & $18.13 \pm 3.20$ \\
$\mathbf{1 1 1}$ & $8.71 \pm 1.25$ & $10.23 \pm 0.40$ & $15.08 \pm 1.46$ \\
$\mathbf{1 1 m}$ & $13.53 \pm 3.16$ & $9.87 \pm 0.97$ & $14.01 \pm 1.61$ \\
$\mathbf{1 1 0}$ & $14.62 \pm 1.68$ & $14.52 \pm 0.90$ & $14.81 \pm 1.99$ \\
$\mathbf{1 1 p}$ & $45.00 \pm 3.59$ & $17.98 \pm 1.38$ & $72.22 \pm 4.38$ \\
$\mathbf{1 1 q}$ & $11.37 \pm 0.77$ & $16.61 \pm 2.04$ & $21.08 \pm 3.53$ \\
$\mathbf{1 1}$ & $23.68 \pm 2.25$ & $9.57 \pm 0.92$ & $23.80 \pm 2.05$ \\
$\mathbf{1 2 a}$ & $13.96 \pm 0.68$ & $9.66 \pm 1.50$ & $23.56 \pm 2.76$ \\
$\mathbf{1 2 b}$ & $16.07 \pm 1.26$ & $7.33 \pm 1.42$ & $16.73 \pm 1.73$ \\
$\mathbf{1 2 d}$ & $18.13 \pm 1.20$ & $19.66 \pm 1.8$ & $11.03 \pm 1.70$ \\
$\mathbf{1 2}$ & $9.42 \pm 1.03$ & $33.21 \pm 3.87$ & $18.06 \pm 2.29$ \\
$\mathbf{1 2 g}$ & $11.00 \pm 2.68$ & $10.05 \pm 1.31$ & $13.34 \pm 1.95$ \\
$\mathbf{1 2 h}$ & $9.37 \pm 0.65$ & $10.62 \pm 0.95$ & $14.13 \pm 2.01$ \\
$\mathbf{1 2 i}$ & $16.58 \pm 2.93$ & $14.64 \pm 1.75$ & $12.85 \pm 2.20$ \\
$\mathbf{1 2 j}$ & $21.60 \pm 3.17$ & $11.95 \pm 1.34$ & $17.58 \pm 2.32$ \\
$\mathbf{1 4}$ & $2.07 \pm 0.29$ & $9.54 \pm 0.57$ & $14.95 \pm 3.57$ \\
$\mathbf{1 5}$ & $9.02 \pm 0.80$ & $6.94 \pm 0.41$ & $10.31 \pm 1.89$
\end{tabular}

${ }^{a} \mathrm{IC}_{50}$ values were presented as the mean $\pm \mathrm{SD}$ (standard error of the mean) from three separated experiments.

effect of compounds 11e, 11i, 14 and oridonin was evaluated in human liver cancer cell line HepG2 and normal liver cell line L$\mathrm{O}_{2}$. Compared with $\mathrm{LO}_{2}$ cells, oridonin was approximately 2 -fold more selective in inhibiting the growth of HepG2 cells. The tested analogues 11i (8.84-fold) and 14 (3.43-fold) exhibited higher selectivity than oridonin (see ESI Table S-2 $\dagger$ ). Particularly, compound $\mathbf{1 1 i}$ seemed to be more selective than oridonin, with an SI (selectivity index, IC $_{50}$ of normal cells/ $\mathrm{IC}_{50}$ of tumor cells) value of 8.84 . These results suggest that these 14-acyl oridonin analogues and novel 6,20-epoxy ent-kaurane diterpenoid analogues may serve as promising antitumor agents.
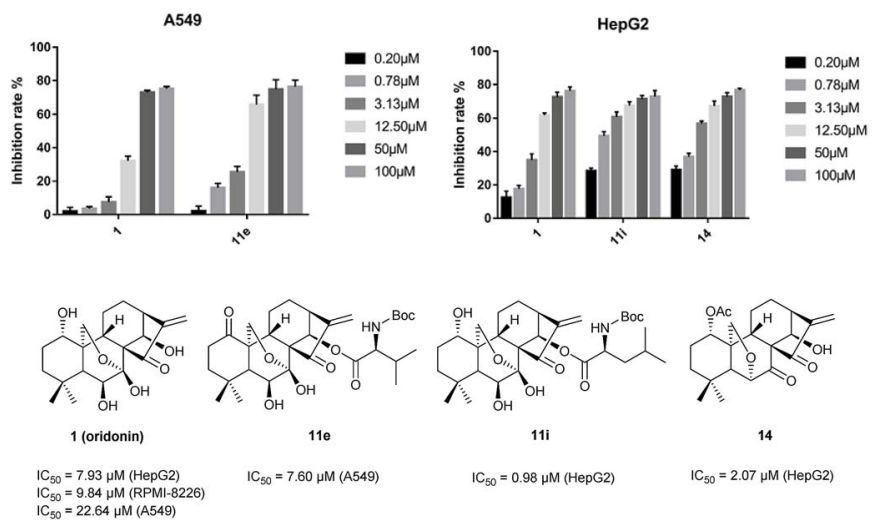

Fig. 2 Comparison of the activity and $\mathrm{IC}_{50}$ of $1,11 \mathrm{e}$ in inhibiting A549 and 1, 11i, 14 in inhibiting HepG2.

\section{Conclusions}

In summary, we report a novel and concise protocol for syntheses of 6,20-epoxy ent-kaurane diterpenoid analogues from oridonin with $\alpha$-methylene cyclopentanone core intact. The reaction features mild conditions and good yield. Remarkably, the prepared 14-acyl oridonin analogues 11e, 11i and 6,20-epoxy ent-kaurane diterpenoid analogue 14 exhibited superior anticancer activities compared to oridonin in vitro. Oridonin was endowed with more potent bioactivities via chemical modification, which will open a new avenue for development of novel anticancer agents. The further anticancer activity investigation of oridonin analogues is under the way.

\section{Experimental}

\section{Chemistry section}

Unless otherwise stated, all commercial reagents were used without additional purification and solvents were distilled prior to use. All reactions were carried out under nitrogen atmosphere. ${ }^{1} \mathrm{H}$ NMR and ${ }^{13} \mathrm{C} \mathrm{NMR}$ spectra were recorded in $\mathrm{CDCl}_{3}$ at $500 \mathrm{MHz}$, using $\mathrm{CDCl}_{3}$ as a reference standard $(\delta=7.26 \mathrm{ppm})$ for ${ }^{1} \mathrm{H}$ NMR and ( $\left.\delta=77.00 \mathrm{ppm}\right)$ for ${ }^{13} \mathrm{C}$ NMR or DMSO-d6 as a reference standard $(\delta=2.50 \mathrm{ppm})$ for ${ }^{1} \mathrm{H}$ NMR and $(\delta=39.52$ ppm) for ${ }^{13} \mathrm{C}$ NMR. Melting points were measured with a Laboratory Device MEL-TEMP and were uncorrected. TLC was performed using commercially prepared silica gel plates (GF254), and visualization was effected at $254 \mathrm{~nm}$ and $365 \mathrm{~nm}$. High resolution mass spectra (HRMS) were recorded on the Exact Mass Spectrometer equipped with ESI ionization source.

\section{General procedure for the synthesis of compounds 11a-11r}

To a stirring solution of oridonin $(500 \mathrm{mg}, 1.37 \mathrm{mmol})$ in acetone $(40 \mathrm{~mL})$ was added Jones reagent $(0.6 \mathrm{~mL})$ dropwise at ice-water bath. The resulting mixture was stirred at $0{ }^{\circ} \mathrm{C}$ for $20 \mathrm{~min}$, and isopropyl alcohol was added to quench excess Jones reagent. Then the mixture was diluted with water and extracted with dichloromethane $(3 \times 10 \mathrm{~mL})$. The extract was then washed with brine, dried over anhydrous $\mathrm{MgSO}_{4}$, filtered, and evaporated to give a solid crude product. The crude residue was recrystallized from acetone-hexane to give compound 10a as a white solid, $440 \mathrm{mg}, 88 \%$ yield.

Treatment of oridonin (500 mg, $1.37 \mathrm{mmol}$ ) with 2,2-dimethoxypropane in the presence of $p$-TsOH in acetone afforded 7,14-(1-methylethylene)-dioxy-oridonin derivative (498 mg, 1.23 $\mathrm{mmol}$ ) in $90 \%$ yield. Subsequently, this derivative (200 $\mathrm{mg}, 0.50$ mmol) was treated with $\mathrm{Ac}_{2} \mathrm{O}(0.05 \mathrm{~mL}, 0.50 \mathrm{mmol}), \mathrm{Et}_{3} \mathrm{~N}(1 \mathrm{~mL})$ and DMAP (183 $\mathrm{mg}, 1.50 \mathrm{mmol}$ ) in $15 \mathrm{~mL}$ dichloromethane to yield the corresponding compound 13 (221 $\mathrm{mg}$, 91\% yield). Deprotection of compound 13 (200 mg, $0.44 \mathrm{mmol}$ ) with $2 \%$ $\mathrm{HCl}$ solution in $10 \mathrm{~mL}$ tetrahydrofuran gave the corresponding compound $10 b$ (155 mg, 87\% yield).

Compound 10a (100 mg, $0.25 \mathrm{mmol}$ ) was mixed with 4methoxycinnamic acid (50 mg, $0.25 \mathrm{mmol}$ ), EDCI (143 mg, 0.75 $\mathrm{mmol}$ ) and DMAP (92 $\mathrm{mg}, 0.75 \mathrm{mmol}$ ) in $10 \mathrm{~mL}$ anhydrous dichloromethane, and the resulting mixture was stirred under 
nitrogen atmosphere at room temperature overnight. The reaction was poured into $1 \mathrm{M} \mathrm{HCl}$ solution, and the mixture was extracted with dichloromethane $(3 \times 5 \mathrm{~mL})$. The organic layers were combined, washed with water and saturated $\mathrm{NaCl}$ solution, dried over anhydrous $\mathrm{MgSO}_{4}$, filtered, and concentrated in vacuo. The crude product was purified by column chromatography $\left(\mathrm{SiO}_{2}, \mathrm{DCM} / \mathrm{MeOH}\right)$ to give the compound 11a. White solid, mp $136-137^{\circ} \mathrm{C} .121 \mathrm{mg}, 83 \%$ yield. $R_{\mathrm{f}}=0.35$ (1: $25 \mathrm{MeOH}$ in $\left.\mathrm{CH}_{2} \mathrm{Cl}_{2}\right)$; ${ }^{1} \mathrm{H} \mathrm{NMR}\left(500 \mathrm{MHz}, \mathrm{CDCl}_{3}\right) \delta 7.60(\mathrm{~d}, J=15.9 \mathrm{~Hz}, 1 \mathrm{H}), 7.44(\mathrm{~d}, J=$ $8.7 \mathrm{~Hz}, 2 \mathrm{H}), 6.88(\mathrm{t}, J=5.8 \mathrm{~Hz}, 2 \mathrm{H}), 6.27(\mathrm{~s}, 1 \mathrm{H}), 6.20(\mathrm{~d}, J=$ $15.9 \mathrm{~Hz}, 1 \mathrm{H}), 5.92(\mathrm{~s}, 1 \mathrm{H}), 5.62(\mathrm{~d}, J=0.9 \mathrm{~Hz}, 1 \mathrm{H}), 5.47$ (d, $J=$ $8.8 \mathrm{~Hz}, 1 \mathrm{H}$ ), 4.32 (dd, $J=10.6,1.0 \mathrm{~Hz}, 1 \mathrm{H}), 4.05$ (dd, $J=10.6$, $1.5 \mathrm{~Hz}, 1 \mathrm{H}), 3.83(\mathrm{~d}, J=6.1 \mathrm{~Hz}, 3 \mathrm{H}), 3.25$ (d, $J=9.6 \mathrm{~Hz}, 1 \mathrm{H}), 2.62$ (dt, $J=14.0,8.8 \mathrm{~Hz}, 1 \mathrm{H}), 2.47$ (ddd, $J=15.4,10.9,6.6 \mathrm{~Hz}, 1 \mathrm{H}$ ), 2.38-2.24 (m, 3H), 2.08-2.01 (m, 1H), 1.99 (d, $J=8.6 \mathrm{~Hz}, 1 \mathrm{H})$, 1.95-1.87 (m, 1H), 1.74 (ddd, $J=13.8,8.8,6.7 \mathrm{~Hz}, 2 \mathrm{H}), 1.68-1.60$ (m, 1H), 1.37-1.30 (m, 1H), $1.21(\mathrm{~s}, 3 \mathrm{H}), 1.01(\mathrm{~s}, 3 \mathrm{H}) .{ }^{13} \mathrm{C}$ NMR $\left(125 \mathrm{MHz}, \mathrm{CDCl}_{3}\right) d$ 211.78, 204.97, 165.43, 161.79, 149.32, 146.32, 130.08, 126.56, 122.20, 114.37, 114.06, 97.13, 75.54, 73.03, $64.93,61.18,60.35,55.39,50.77,48.56,41.32$, 38.54, 35.83, 32.89, 30.53, 30.00, 29.69, 23.30, 19.05. HRMS ( $\mathrm{m} / \mathrm{z}$ ) (ESI): calcd for $\mathrm{C}_{30} \mathrm{H}_{35} \mathrm{O}_{8} 523.2326[\mathrm{M}+\mathrm{H}]^{+}$found 523.2318.

All of the products $\mathbf{1 1 b} \mathbf{- 1 1 r}$ were synthesized according to above described procedure.

\section{General procedure for the synthesis of compounds $12 \mathrm{a}-12 \mathrm{k}$}

Compound 11a (94 mg, $0.18 \mathrm{mmol}$ ) was mixed with $0.24 \mathrm{~mL}$ DAST (diethylaminosulfur trifluoride) in anhydrous dichloromethane $(10 \mathrm{~mL})$, and the resulting mixture was stirred under nitrogen atmosphere at $-78{ }^{\circ} \mathrm{C}$ for $10 \mathrm{~min}$, then warmed up to room temperature and stirred for $2 \mathrm{~h}$. The mixture was poured into water, and extracted with dichloromethane $(3 \times 5 \mathrm{~mL})$. The organic layers were combined, washed with water and saturated $\mathrm{NaCl}$ solution, dried over anhydrous $\mathrm{MgSO}_{4}$, filtered, and concentrated in vacuo. The crude product was purified by column chromatography (petroleum ether/ethyl acetate) to give the compound 12a. White solid, mp 119-120 ${ }^{\circ} \mathrm{C} .73 \mathrm{mg}, 81 \%$ yield. $R_{\mathrm{f}}$ $=0.46\left(1: 1\right.$ petroleum ether/ethyl acetate); ${ }^{1} \mathrm{H}$ NMR $(500 \mathrm{MHz}$, $\left.\mathrm{CDCl}_{3}\right) \delta 7.58(\mathrm{~d}, J=15.9 \mathrm{~Hz}, 1 \mathrm{H}), 7.44(\mathrm{~d}, J=8.7 \mathrm{~Hz}, 2 \mathrm{H}), 6.86(\mathrm{~d}$, $J=8.7 \mathrm{~Hz}, 2 \mathrm{H}), 6.20(\mathrm{~d}, J=15.9 \mathrm{~Hz}, 1 \mathrm{H}), 6.16(\mathrm{~s}, 1 \mathrm{H}), 5.72(\mathrm{~s}, 1 \mathrm{H})$, $5.50(\mathrm{~s}, 1 \mathrm{H}), 4.38(\mathrm{~d}, J=9.7 \mathrm{~Hz}, 1 \mathrm{H}), 4.31-4.26(\mathrm{~m}, 2 \mathrm{H}), 3.82(\mathrm{~s}$, $3 \mathrm{H}), 3.23(\mathrm{~d}, J=7.9 \mathrm{~Hz}, 1 \mathrm{H}), 2.74$ (ddd, $J=14.6,11.7,6.3 \mathrm{~Hz}, 1 \mathrm{H}$ ), 2.56-2.45 (m, 2H), $2.35(\mathrm{dt}, J=14.6,4.6 \mathrm{~Hz}, 1 \mathrm{H}), 2.18-2.10(\mathrm{~m}$, $2 \mathrm{H}), 1.96-1.81(\mathrm{~m}, 3 \mathrm{H}), 1.77-1.69(\mathrm{~m}, 1 \mathrm{H}), 1.66(\mathrm{~s}, 1 \mathrm{H}), 1.19(\mathrm{~d}, J=$ $15.1 \mathrm{~Hz}, 3 \mathrm{H}), 1.05(\mathrm{~s}, 3 \mathrm{H}) .{ }^{13} \mathrm{C} \mathrm{NMR}\left(125 \mathrm{MHz}, \mathrm{CDCl}_{3}\right) \delta 209.87$, 202.56, 199.65, 166.04, 161.48, 147.69, 145.74, 129.98, 126.97, 119.22, 114.68, 114.21, 83.31, 77.27, 77.01, 76.76, 75.61, 70.10, 64.24, 61.58, 61.31, 55.34, 47.17, 42.05, 41.18, 36.37, 31.96, 31.33, $30.17,29.68,23.23,19.17$. HRMS (m/z) (ESI): calcd for $\mathrm{C}_{30} \mathrm{H}_{33} \mathrm{O}_{7}$ $505.2221[\mathrm{M}+\mathrm{H}]^{+}$found 505.2218.

All of the products $\mathbf{1 2 b}-\mathbf{1 2} \mathbf{j}$ were synthesized according to above described procedure.

\section{General procedure for the synthesis of compound 14}

Compound 13 (100 mg, $0.22 \mathrm{mmol}$ ) was mixed with $0.30 \mathrm{~mL}$ DAST (diethylaminosulfur trifluoride) in anhydrous dichloromethane $(10 \mathrm{~mL})$ and the resulting mixture was stirred under nitrogen atmosphere at $-78{ }^{\circ} \mathrm{C}$ for $10 \mathrm{~min}$, then warmed up to room temperature and stirred for $2 \mathrm{~h}$. The mixture was poured into water, and the mixture was extracted with dichloromethane thrice $(3 \times 5 \mathrm{~mL})$. The organic layers were combined, washed with brine, dried over anhydrous $\mathrm{MgSO}_{4}$, filtered and concentrated in vacuo. The crude product was purified by column chromatography $(6: 1$ petroleum ether/ ethyl acetate) to give the compound 14. Yellow solid, mp 115$116{ }^{\circ} \mathrm{C} .77 \mathrm{mg}, 89 \%$ yield. $R_{\mathrm{f}}=0.27$ (1: 1 petroleum ether/ethyl acetate); ${ }^{1} \mathrm{H}$ NMR (500 MHz, $\left.\mathrm{CDCl}_{3}\right) \delta 6.13(\mathrm{~s}, 1 \mathrm{H}), 5.53(\mathrm{~s}, 1 \mathrm{H})$, $4.88(\mathrm{dd}, J=10.9,6.0 \mathrm{~Hz}, 1 \mathrm{H}), 4.88(\mathrm{dd}, J=10.9,6.0 \mathrm{~Hz}, 1 \mathrm{H})$, $4.74(\mathrm{~s}, 2 \mathrm{H}), 4.58(\mathrm{~s}, 1 \mathrm{H}), 4.17(\mathrm{~s}, 1 \mathrm{H}), 4.12(\mathrm{~d}, J=10.0 \mathrm{~Hz}, 1 \mathrm{H})$, $4.10(\mathrm{q}, J=10.0 \mathrm{~Hz}, 2 \mathrm{H}), 4.09(\mathrm{~d}, J=10.0 \mathrm{~Hz}, 1 \mathrm{H}), 3.83(\mathrm{dd}, J=$ 43.1, $15.7 \mathrm{~Hz}, 1 \mathrm{H}), 3.11$ (d, $J=8.7 \mathrm{~Hz}, 1 \mathrm{H}), 3.11$ (d, $J=8.7 \mathrm{~Hz}$, $1 \mathrm{H}), 2.44-2.35(\mathrm{~m}, 1 \mathrm{H}), 2.45-2.33(\mathrm{~m}, 1 \mathrm{H}), 2.19$ (dd, $J=12.2$, $6.1 \mathrm{~Hz}, 1 \mathrm{H}), 2.19$ (dd, $J=12.2,6.1 \mathrm{~Hz}, 1 \mathrm{H}), 1.99(\mathrm{~s}, 3 \mathrm{H}), 1.89$ (s, $1 \mathrm{H}), 1.64-1.57$ (m, 2H), 1.49 (s, 1H), 1.41 (d, $J=8.7 \mathrm{~Hz}, 1 \mathrm{H}), 1.21$ (s, 1H), 1.04 (s, 3H), 1.01 (s, 3H). ${ }^{13} \mathrm{C} \mathrm{NMR} \mathrm{(125} \mathrm{MHz,} \mathrm{CDCl}_{3}$ ) $\delta$ 205.36, 203.22, 169.94, 149.04, 120.20, 82.53, 76.74, 73.59, $68.21,64.94,55.04,52.97,51.04,43.79,36.97,32.26,30.83$, 29.68, 29.37, 24.60, 22.45, 21.40, 18.95. HRMS ( $\mathrm{m} / \mathrm{z}$ ) (ESI): calcd for $\mathrm{C}_{22} \mathrm{H}_{29} \mathrm{O}_{6} 389.1959[\mathrm{M}+\mathrm{H}]^{+}$found 389.1959.

\section{General procedure for the synthesis of compound 15}

Compound 11d (50 mg, $0.08 \mathrm{mmol})$ was mixed with $(E)-3-(3,4-$ dimethoxyphenyl)acrylic acid (33 $\mathrm{mg}, 0.16 \mathrm{mmol}$ ), $0.11 \mathrm{~mL}$ DAST (diethylaminosulfur trifluoride) in anhydrous dichloromethane $(10 \mathrm{~mL})$ and the resulting mixture was stirred under nitrogen atmosphere at $-78{ }^{\circ} \mathrm{C}$ for $10 \mathrm{~min}$, then warmed up to room temperature and stirred overnight. The mixture was poured into water, and the mixture was extracted with dichloromethane thrice $(3 \times 5 \mathrm{~mL})$. The organic layers were combined, washed with brine, dried over anhydrous $\mathrm{MgSO}_{4}$, filtered and concentrated in vacuo. The crude product was purified by column chromatography $(6: 1$ petroleum ether/ ethyl acetate) to give the compound 15. White solid, mp 125$126^{\circ} \mathrm{C} .52 \mathrm{mg}, 83 \%$ yield. $R_{\mathrm{f}}=0.63$ (1: 1 petroleum ether/ethyl acetate); ${ }^{1} \mathrm{H}$ NMR $\left(500 \mathrm{MHz}, \mathrm{CDCl}_{3}\right) \delta 7.88(\mathrm{~d}, J=15.9 \mathrm{~Hz}, 1 \mathrm{H})$, 7.59 (d, $J=15.9 \mathrm{~Hz}, 1 \mathrm{H}), 7.18$ (d, $J=8.3 \mathrm{~Hz}, 1 \mathrm{H}), 7.15(\mathrm{~s}, 1 \mathrm{H})$, $7.04(\mathrm{~d}, J=8.3 \mathrm{~Hz}, 1 \mathrm{H}), 6.99(\mathrm{~s}, 1 \mathrm{H}), 6.88(\mathrm{~d}, J=8.2 \mathrm{~Hz}, 1 \mathrm{H}), 6.81$ $(\mathrm{t}, J=9.1 \mathrm{~Hz}, 1 \mathrm{H}), 6.56(\mathrm{~d}, J=15.9 \mathrm{~Hz}, 1 \mathrm{H}), 6.20(\mathrm{dd}, J=15.8$, $6.4 \mathrm{~Hz}, 1 \mathrm{H}), 6.01(\mathrm{~d}, J=13.7 \mathrm{~Hz}, 2 \mathrm{H}), 5.36-5.31(\mathrm{~m}, 2 \mathrm{H}), 5.02(\mathrm{~s}$, $1 \mathrm{H}), 4.73(\mathrm{dd}, J=11.2,5.5 \mathrm{~Hz}, 1 \mathrm{H}), 4.41(\mathrm{~d}, J=10.6 \mathrm{~Hz}, 1 \mathrm{H}), 4.28$ (t, $J=8.9 \mathrm{~Hz}, 1 \mathrm{H}), 3.93(\mathrm{~d}, J=6.4 \mathrm{~Hz}, 6 \mathrm{H}), 3.89$ (d, $J=5.4 \mathrm{~Hz}$, $6 \mathrm{H}), 3.17(\mathrm{~d}, J=9.9 \mathrm{~Hz}, 1 \mathrm{H}), 2.61-2.53(\mathrm{~m}, 1 \mathrm{H}), 2.36-2.31(\mathrm{~m}$, $1 \mathrm{H}), 2.04(\mathrm{~d}, J=7.4 \mathrm{~Hz}, 3 \mathrm{H}), 1.90-1.78(\mathrm{~m}, 2 \mathrm{H}), 1.71(\mathrm{~d}, J=$ $6.1 \mathrm{~Hz}, 1 \mathrm{H}), 1.56$ (d, $J=12.9 \mathrm{~Hz}, 1 \mathrm{H}), 1.46$ (t, $J=12.7 \mathrm{~Hz}, 1 \mathrm{H})$, 1.40-1.30 (m, 3H), 1.21 (d, $J=8.9 \mathrm{~Hz}, 3 \mathrm{H}), 0.90(\mathrm{~d}, J=8.9 \mathrm{~Hz}$, $3 \mathrm{H}) .{ }^{13} \mathrm{C} \mathrm{NMR}\left(125 \mathrm{MHz}, \mathrm{CDCl}_{3}\right) \delta 200.70,169.93,168.85$, $165.90,151.30$, 151.20, 150.25, 149.16, 146.21, 146.05, 127.58, $127.10,123.20,117.17,115.70,114.89,110.93$, 110.86, 109.77, 109.31, 96.81, 75.94, 75.16, 74.05, 63.40, 60.14, 56.04, 52.18, $41.97,40.46,40.23,37.70,33.68,31.65,30.37,29.68,27.00$, $25.17,21.58,21.38$, 17.82. HRMS $(\mathrm{m} / \mathrm{z})$ (ESI): calcd for $\mathrm{C}_{44} \mathrm{H}_{51} \mathrm{NO}_{13} 787.3324[\mathrm{M}+\mathrm{H}]^{+}$found 787.3342 . 


\section{In vitro cytotoxicity}

The HepG2, RPMI-8226, A549, ${\mathrm{L}-\mathrm{O}_{2}}_{2}$ cell lines used in this study were all purchased from EnoGene company. RPMI-8226 and A549 cells were cultured in RPMI 1640 media containing 10\% heat inactivated FBS and $\mathrm{HepG} 2$ and $\mathrm{L}-\mathrm{O}_{2}$ cells were cultured in DMEM media containing $10 \%$ heat inactivated FBS at $37{ }^{\circ} \mathrm{C}$ with $5 \% \mathrm{CO}_{2}$. In order to investigate the antitumor activity of some compounds, a commercial Paclitaxel (PTX) was used as a positive control drug.

10000 cells of HepG2, RPMI-8226, A549 or ${\mathrm{L}-\mathrm{O}_{2}}_{2}$ were prepared into $200 \mu \mathrm{L}$ cell suspension in each well of 96-well plates and the plates were incubated for $24 \mathrm{~h}$ at $37{ }^{\circ} \mathrm{C}$ with $5 \%$ $\mathrm{CO}_{2} .100 \mu \mathrm{L}$ medium with compounds was mixed into each well of 96-well plates, respectively. And the negative control group, the solvent control group, the positive control group were established, respectively. The plates were incubated for $72 \mathrm{~h}$ at $37{ }^{\circ} \mathrm{C}$ with $5 \% \mathrm{CO}_{2}$. Then $10 \mu \mathrm{L}$ CCK-8 solution was mixed into each well of 96-well plates and the plates were incubated for $4 \mathrm{~h}$. Optical absorbance at $450 \mathrm{~nm}$ was determined with microplate absorbance reader (Bio-Rad). IC $_{50}$ values were calculated from the dose-response curves of the assay (Prism 7.0).

\section{Conflicts of interest}

There are no conflicts to declare.

\section{Acknowledgements}

We are thankful for the financial support from National Natural Science Foundation of China (81561148012, 21572154, 21772181), NSFC-Shandong Joint Fund for Marine Science Research Centers (U1606403) and the Fundamental Research Funds for the Central Universities [201612013].

\section{Notes and references}

1 H. D. Sun, S. X. Huang and Q. B. Han, Nat. Prod. Rep., 2006, 23, 673-698.

2 C. Y. Ding, Y. S. Zhang, H. J. Chen, Z. D. Yang, C. Wild, L. L. Chu, H. L. Liu, Q. Shen and J. Zhou, J. Med. Chem., 2013, 56, 5048-5058.

3 P. H. Abelson, Science, 1990, 247, 513.

4 Y. C. Li, M. R. Sun, Y. H. Zhao, X. Z. Fu, H. W. Xu and J. F. Liu, Cytotechnology, 2016, 68, 389-397.

5 T. Ikezoe, Y. Yang, K. Bandobashi, T. Saito, S. Takemoto, H. Machida, K. Togitani, H. P. Koeffler and H. Taguchi, Mol. Cancer Ther., 2005, 4, 578-586.

6 Q. Cui, S. Tashiro, S. Onodera, M. Minami and T. Ikejima, Biol. Pharm. Bull., 2007, 30, 859-864.

7 C. Y. Li, E. Q. Wang, Y. Cheng and J. K. Bao, Int. J. Biochem. Cell Biol., 2011, 43, 701-704.

8 S. Wang, Z. Zhong, J. Wan, W. Tan, G. Wu, M. Chen and Y. Wang, Am. J. Chin. Med., 2013, 41, 177-196.

9 R. F. Bao, Y. J. Shu, X. S. Wu, H. Weng, Q. Ding, Y. Cao, M. L. Li, J. S. Mu, W. G. Wu, Q. C. Ding, Z. J. Tan,
T. Y. Liu, L. Jiang, Y. P. Hu, J. F. Gu and Y. B. Liu, $B M C$ Cancer, 2014, 14, 217.

10 Y. Dong, T. Zhang, J. J. Li, H. Y. Deng, Y. J. Song, D. Zhai, Y. Peng, X. L. Lu, M. Y. Liu, Y. X. Zhao and Z. F. Yi, PLoS One, 2014, 9, e113830.

11 Y. Li, Y. Wang, S. Wang, Y. Gao, X. Zhang and C. Lu, Med. Oncol., 2015, 32, 365.

12 M. Zheng, Z. Zhu, Y. Zhao, D. Yao, M. Wu and G. Sun, Mol. Med. Rep., 2017, 15, 375-379.

13 J. Yang, X. Ren, L. Zhang, Y. Li, B. Cheng and J. Xia, Biomed. Pharmacother., 2018, 100, 226-232.

14 T. Zhang, Y. Tan, R. Zhao and Z. Y. Liu, Wspolczesna Onkol., 2013, 17, 38-44.

15 D. L. Liu, H. Q. Bu, H. M. Jin, J. F. Zhao, Y. Li and H. Huang, Mol. Med. Rep., 2014, 10, 3027-3034.

16 S. Y. Gao, H. X. Tan, N. Zhu, H. Y. Gao, C. Y. Lv, J. Gang and Y. B. Ji, Internet J. Oncol., 2016, 48, 2453-2460.

17 S. T. Xu, S. S. Luo, H. Yao, H. Cai, X. M. Miao, F. Wu, D. H. Yang, X. M. Wu, W. J. Xie, H. Q. Yao, Z. S. Chen and J. Y. Xu, J. Med. Chem., 2016, 59, 5022-5034.

18 S. T. Xu, H. Yao, S. S. Luo, Y. K. Zhang, D. H. Yang, D. H. Li, G. Y. Wang, M. Hu, Y. Y. Qiu, X. M. Wu, H. Q. Yao, W. J. Xie, Z. S. Chen and J. Y. Xu, J. Med. Chem., 2017, 60, 1449-1468.

19 G. B. Zhou, H. Kang, L. Wang, L. Gao, P. Liu, J. Xie, F. X. Zhang, X. Q. Weng, Z. X. Shen, J. Chen, L. J. Gu, M. Yan, D. E. Zhang, S. J. Chen, Z. Y. Wang and Z. Chen, Blood, 2007, 109, 3441-3450.

20 W. Xu, J. Sun, T. T. Zhang, B. Ma, S. M. Cui, D. W. Chen and Z. G. He, Acta Pharmacol. Sin., 2006, 27, 1642-1646.

21 Y. H. Ma, W. W. Xie, T. T. Tian, Y. R. Jin, H. J. Xu, K. R. Zhang and Y. F. Du, Anal. Biochem., 2016, 511, 61-73.

22 E. Fujita, Y. Nagao, K. Kaneko, S. Nakazawa and H. Kuroda, Chem. Pharm. Bull., 1976, 24, 2118-2127.

23 E. Fujita, Y. Nagao, T. Kohno, M. Matsuda and M. Ozaki, Chem. Pharm. Bull., 1981, 29, 3208-3213.

24 M. Zhang, Y. M. Zhang, W. Lu and F. J. Nan, Org. Biomol. Chem., 2011, 9, 4436-4439.

25 S. X. Huang, Y. Zhou, J. X. Pu, R. T. Li, M. Li, W. L. Xiao, L. G. Lou, Q. B. Han, L. S. Ding, S. L. Peng and H. D. Sun, Tetrahedron, 2006, 62, 4941-4947.

26 C. Ding, Y. Zhang, H. Chen, Z. Yang, C. Wild, N. Ye, C. D. Ester, A. Xiong, M. A. White, Q. Shen and J. Zhou, J. Med. Chem., 2013, 56, 8814-8825.

27 C. Y. Ding, Y. S. Zhang, H. J. Chen, C. Wild, T. Z. Wang, M. A. White, Q. Shen and J. Zhou, Org. Lett., 2013, 15, 3718-3721.

28 C. Ding, L. Wang, H. Chen, C. Wild, N. Ye, Y. Ding, T. Wang, M. A. White, Q. Shen and J. Zhou, Org. Biomol. Chem., 2014, 12, 8442-8452.

29 X. B. Yan, M. Lei, Y. J. Zhang and H. M. Liu, Chin. J. Org. Chem., 2005, 25, 222-224.

30 J. Y. Xu, J. Y. Yang, Q. Ran, L. Wang, J. Liu, Z. X. Wang, X. M. Wu, W. Y. Hua, S. T. Yuan, L. Y. Zhang, M. Q. Shen and Y. F. Ding, Bioorg. Med. Chem. Lett., 2008, 18, 4741-4744.

31 D. H. Li, L. Wang, H. Cai, Y. H. Zhang and J. Y. Xu, Molecules, 2012, 17, 7556-7568. 
32 S. E. Boiadjiev and D. A. Lightner, J. Org. Chem., 1997, 62, 399-404.

33 T. Mase, I. N. Houpis, A. Akao, I. Dorziotis, K. Emerson, T. Hoang, T. Iida, T. Itoh, K. Kamei, S. Kato, Y. Kato, M. Kawasaki, F. Lang, J. Lee, J. Lynch, P. Maligres, A. Molina, T. Nemoto, S. Okada, R. Reamer, J. Z. Song, D. Tschaen, T. Wada, D. Zewge, R. P. Volante, P. J. Reider and K. Tomimoto, J. Org. Chem., 2001, 66, 6775-6786.

34 K. Suzuki, Y. Ito and O. Kanie, Carbohydr. Res., 2012, 359, 8191.

35 P. BorracheroMoya, F. CabreraEscribano, M. GomezGuillen and F. MadridDiaz, Tetrahedron Lett., 1997, 38, 1231-1234.
36 P. Borrachero, F. Cabrera-Escribano, A. T. Carmona and M. Gomez-Guillen, Tetrahedron: Asymmetry, 2000, 11, 29272946.

37 T. S. Lin, W. T. Tsai and P. H. Liang, Tetrahedron, 2016, 72, 5571-5577.

38 C. Yang, I. L. Wong, K. Peng, Z. Liu, P. Wang, T. Jiang, T. Jiang, L. M. Chow and S. B. Wan, Eur. J. Med. Chem., 2017, 125, 795-806.

39 I. L. Wong, B. C. Wang, J. Yuan, L. X. Duan, Z. Liu, T. Liu, X. M. Li, X. Hu, X. Y. Zhang, T. Jiang, S. B. Wan and L. M. Chow, J. Med. Chem., 2015, 58, 4529-4549. 